\title{
Priimek Vram
}

\author{
Pavle Merkù
}

IZVLEČEK: Avtor končni -m v tržaškem priimku Vram v primerjavi $s$ splošnoslovenskima variantama Vran in Uran razlaga $z$ vplivom tergestinskega narečja.

\section{The Surname Vram}

ABSTACT: The author explains the final $-m$ in the Trieste surname Vram in comparison to the general Slovenian variants Vran and Uran as Tergestine dialect influence.

$\mathrm{V}$ tej obliki je priimek zelo redek: prisoten je v preteklosti v Zgoniku na tržaškem Krasu, kjer je ista oseba zapisana 1525 Iacob(us) Vram de Suonicho/Yuonico = Vragm Jacob de Xuonicho = Iacob Vran de Xuonicho = Iacob Vranich de Xuonicho; danes je prisoten samo $\mathrm{v}$ Trstu in verjetno spadajo vsi nosilci $\mathrm{k}$ isti družini. $\mathrm{V}$ začetku 20. stoletja je bila v Trstu privatna glasbena šola Liceo musicale Arturo Vram, pri kateri sta tako moj oče kakor moja mati študirala violino: tu sta se sploh spoznala. Arturo Vram je bil odločen pedagog, ki se je izpopolnjeval v Pragi pri O. Ševčíku. $\mathrm{V}$ tržaškem telefonskem imeniku za leto 2008 je prisoten en sam Vram, obenem tudi en sam Vran.

Priimkovne oblike s izglasnim - $m$ nisem nikoli srečal nikjer drugje.

Pač pa je po vsej Sloveniji razširjena priimkovna oblika s izglasnim -n: Vran. ZSSP$^{1}$ ga omenja v štirih okrajih, po enega na Gorenjskem, Dolenjskem, Štajerskem in Primorskem v Sežani. V pisni obliki Uran je priimek razširjen v desetih okrajih, ki zaobjamejo vso Slovenijo. Gre za pisno različico dobro znanega ornitonima vrán 'corvus'. Nikjer ni zabeležen Vram ali *Uram.

Edina možna razlaga oblike $\mathrm{z}$ izglasnim $-m$ je, da je notar zapisal $1.1525 \mathrm{v}$ Zgoniku priimek s tergestinskim narečnim prehodom izglasnega $-n>-m$. Ali pa da se je prvotni priimek Vran, naj je prišel v Trst iz Sežane ali Zgonika ali drugega kraja, pojavil v Trstu dovolj zgodaj, da se je tu prilikoval tergestinskemu narečju, to je prvotnemu furlanskemu narečju, ki je v mestu nastalo dolgo pred italijanskim tržaškim narečjem. V tergestinskem narečju se namreč izglasni -n spreminja v - $m$; npr. tergestinsko bom vim : tržaško bon vin 'dobro vino'.

1 Začasni slovar slovenskih priimkov, redaktor France Bezlaj, SAZU, Ljubljana, 1974. 
To narečje so v mestu govorili predvsem tržaški plemiči in imenitnejše družine vsaj do 18. stol., v pojemajočem in vedno redkejšem številu do leta 1914, ko je družina Cùmano zapustila Trst: o njej poroča Giuseppina Antonini Perusini v svoji avtobiografski knjigi Un secolo nella memoria, da so njeni člani zadnji v Trstu govorili po tergestinsko. Je bil prvi tržaški Vram morda uslužbenec pri kaki tržaški plemiški ali imovitejši družini, pri kateri so slovenski priimek z izglasnim -n lahko izgovarjali z - $m$ ?

Vsekakor je to izredno redek hibridni slovensko-tergestinski priimek. ${ }^{2}$

2 Ker je priimek Vram izvorno slovenski in se v slovenščini prehod $n>m$ pred labialnimi konzonanti potrjuje v morfemskih (npr. hramba $<*$ hran-ba $\leftarrow$ hraniti) in skladenjskih stikih (npr. ampak < *an pak »in vendar«), na zahodnem območju pa je izpričan v Videmskem rokopisu (1458), dobro potrjen v Alasijevem slovarju (1607) in znan tudi v nadiškem narečju, kjer se v krajih Idrsko in Jevšček tudi toponim Videm, it. Ùdine, furl. Ùdin glasi Í:dəm oz. Í:dem, bi bilo priimek Vram mogoče razložiti tudi s to slovensko fonetiko. (Lit.: Metka Furlan, Slovenščina v Alasijevem Italijansko-slovenskem slovarju iz leta 1607, Živeti mejo (Zbornik Slavističnega društva Slovenije 18), Trst, 2007, 304 z op. 34; Matej Šekli, Naglas nekaterih predslovanskih substratnih krajevnih imen moškega spola v slovenščini, 42. SSJLK 26. 6.-14. 7. 2006, Ljubljana, 224.)

Po podatkih Statističnega urada Republike Slovenije je bilo leta 2007 v Sloveniji 95 oseb s priimkom Vran (4532. mesto) in 194 oseb s priimkom Uran (2214. mesto) [Op. ur.] 